\title{
Preparation of $\mathrm{SrGd}_{2}\left(\mathrm{MoO}_{4}\right)_{4}: \mathrm{Er}^{3+} / \mathrm{Yb}^{3+}$ Phosphors by the Microwave-Modi- fied Sol-Gel Method and Their Upconversion Photoluminescence Properties
}

\author{
Chang Sung Lim ${ }^{\dagger}$ \\ Department of Advanced Materials Science \& Engineering, Hanseo University, Seosan 356-706, Republic of Korea
}

(Received July 29, 2014; Revised September 6, 2014; Accepted September 15, 2014)

\begin{abstract}
$\mathrm{SrGd}_{2-\mathrm{x}}\left(\mathrm{MoO}_{4}\right)_{4}: \mathrm{Er}^{3+} / \mathrm{Yb}^{3}$ phosphors with doping concentrations of $\mathrm{Er}^{3+}$ and $\mathrm{Yb}^{3+}\left(\mathrm{x}=\mathrm{Er}^{3+}+\mathrm{Yb}^{3+}, \mathrm{Er}^{3+}=0.05,0.1,0.2\right.$, and $\mathrm{Yb}^{3+}=$ $0.2,0.45)$ were successfully synthesized by the cyclic microwave-modified sol-gel method, and their upconversion mechanism and spectroscopic properties have been investigated in detail. Well-crystallized particles showed a fine and homogeneous morphology with grain sizes of 2-5 $\mathrm{mm}$. Under excitation at $980 \mathrm{~nm}, \operatorname{SrGd}_{1.7}\left(\mathrm{MoO}_{4}\right)_{4}: \mathrm{Er}_{0.1} \mathrm{Yb}_{0.2}$ and $\operatorname{SrGd}_{1.5}\left(\mathrm{MoO}_{4}\right)_{4}: \mathrm{Er}_{0.05} \mathrm{Yb}_{0.45}$ particles exhibited a strong 525-nm emission band, a weak 550-nm emission band in the green region, and a very weak 655-nm emission band in the red region. The Raman spectra of the doped particles indicated the domination of strong peaks at higher frequencies of 1023,1092 , and $1325 \mathrm{~cm}^{-1}$ and at lower frequencies of $223,2932,365,428,538$, and $594 \mathrm{~cm}^{-1}$ induced by the incorporation of the $\mathrm{Er}^{3+}$ and $\mathrm{Yb}^{3+}$ elements into the $\mathrm{Gd}^{3+}$ site in the crystal lattice, which resulted in the unit cell shrinkage accompanying a new phase formation of the $\left[\mathrm{MoO}_{4}\right]^{2-}$ groups.
\end{abstract}

Key words : Phosphor, Upconversion, Sol-gel, Raman spectroscopy

\section{Introduction}

$\mathbf{R}$ ecently, rare earth doped upconversion (UC) photoluminescence particles have attracted great attention because of the conversion from near-infrared radiation of low energy to visible radiation of high energy. These UC photoluminescence particles have potential applications in various fields, including biomedical imaging, owing to their unique UC optical behaviors that offer improved light penetration depth, high chemical and photo stability, the absence of auto-fluorescence during imaging, sharp emission bands, and high resistance to photobleaching. These properties overcome many of the current limitations in traditional photoluminescence materials. ${ }^{1-3)}$ The double molybdate compounds of $\mathrm{MR}_{2}\left(\mathrm{MoO}_{4}\right)_{4}$ (M: bivalent alkaline earth metal ion, $\mathrm{R}$ : trivalent rare earth ion) belong to a group of double alkaline earth lanthanide molybdates. With the decrease in the ionic radius of alkaline earth metal ions $\left(\mathrm{R}_{\mathrm{Ca}}<\mathrm{R}_{\mathrm{Sr}}<\mathrm{R}_{\mathrm{Ba}} ; \mathrm{R}=\right.$ ionic radius), it is possible for the structure of $\mathrm{MR}_{2}\left(\mathrm{MoO}_{4}\right)_{4}$ to be transformed to a highly disordered tetragonal scheelite structure from the monoclinic structure. It is possible for the trivalent rare earth ions in the disordered tetragonal-phase to be partially substituted by $\mathrm{Er}^{3+}$ and $\mathrm{Yb}^{3+}$ ions. These ions are effectively doped into the crystal lattices of the tetragonal phase due to the similar radii of the trivalent rare earth ions in $R^{3+}$, and this results

${ }^{\dagger}$ Corresponding author: Chang Sung Lim

E-mail : cslim@hanseo.ac.kr

$\mathrm{Tel} / \mathrm{Fa}:+82-41-660-1445 \quad$ Fax $:+82-41-660-1445$ in the excellent UC photoluminescence properties. ${ }^{4-6)}$ Among rare earth ions, the $\mathrm{Er}^{3+}$ ion is suitable for converting infrared to visible light through the UC process due to its appropriate electronic energy level configuration. Co-doped $\mathrm{Yb}^{3+}$ ions and $\mathrm{Er}^{3+}$ ions can remarkably enhance the UC efficiency for the shift from infrared to visible light due to the efficiency of the energy transfer from $\mathrm{Yb}^{3+}$ to $\mathrm{Er}^{3+}{ }^{3+}$ The $\mathrm{Yb}^{3+}$ ion, as a sensitizer, can be effectively excited by an incident light source energy. This energy is transferred to the activator from which radiation can be emitted. The $\mathrm{Er}^{3+}$ ion activator is the luminescence center of the UC particles, while the sensitizer enhances the UC luminescence efficiency. ${ }^{7-9)}$

Recently, rare earth activated $\mathrm{MR}_{2}\left(\mathrm{MoO}_{4}\right)_{4}(\mathrm{M}=\mathrm{Ba}, \mathrm{Sr}$, $\mathrm{Ca} ; \mathrm{R}=\mathrm{La}, \mathrm{Gd}, \mathrm{Y}$ ) has attracted great attention because of the its spectroscopic characteristics and excellent upconversion photoluminescence properties. Several processes have been developed to prepare these rare-earth-doped double molybdates, including solid-state reactions, ${ }^{9-14)}$ co-precipitation, ${ }^{15,16)}$ the sol-gel method, ${ }^{4-7)}$ the hydrothermal method, ${ }^{17,18)}$ the Pechini method, ${ }^{1920)}$ organic gel-thermal decomposition, ${ }^{21)}$ and the microwave-assisted hydrothermal method. ${ }^{22)}$ For practical application of UC photoluminescence in products such as lasers, three-dimensional displays, light-emitting devices, and biological detectors, features such as the homogeneous UC particle size distribution and morphology need to be well defined. Usually, double molybdates are prepared by a solid-state method that requires high temperatures, a lengthy heating process and subsequent grinding; this results in a loss of the emission intensity and an increase in cost. The sol-gel process provides some advantages over the conventional solid-state method, including 
good homogeneity, low calcination temperature, small particle size and narrow particle size distribution optimal for good luminescent characteristics. However, the sol-gel process has a disadvantage in that it takes a long time for gelation. Compared with the usual methods, microwave synthesis has the advantages of a very short reaction time, small-size particles, narrow particle size distribution, and high purity of the final polycrystalline samples. Microwave heating is delivered to the material surface by radiant and/ or convection heating, which is transferred to the bulk of the material via conduction. ${ }^{23,24)}$ The cyclic microwave-modified sol-gel process is a cost-effective method that provides high homogeneity and is easy to scale-up, and it is emerging as a viable alternative approach for the quick synthesis of highquality luminescent materials.

In this study, $\operatorname{SrGd}_{2-\mathrm{x}}\left(\mathrm{MoO}_{4}\right)_{4}: \mathrm{Er}^{3+} / \mathrm{Yb}^{3+}$ phosphors with doping concentrations of $\mathrm{Er}^{3+}$ and $\mathrm{Yb}^{3+}\left(\mathrm{x}=\mathrm{Er}^{3+}+\mathrm{Yb}^{3+}, \mathrm{Er}^{3+}=\right.$ $0.05,0.1,0.2$, and $\left.\mathrm{Yb}^{3+}=0.2,0.45\right)$ phosphors were prepared by the cyclic microwave-modified sol-gel method for the first time. The synthesized particles were characterized by X-ray diffraction (XRD), scanning electron microscopy (SEM), and energy-dispersive X-ray spectroscopy (EDS). The optical properties were examined comparatively using photoluminescence (PL) emission and Raman spectroscopy.

\section{Experimental Procedure}

Appropriate stoichiometric amounts of $\mathrm{Sr}\left(\mathrm{NO}_{3}\right)_{2} \cdot 4 \mathrm{H}_{2} \mathrm{O}$ (99\%, Sigma-Aldrich, USA), $\mathrm{Gd}\left(\mathrm{NO}_{3}\right)_{3} \cdot 6 \mathrm{H}_{2} \mathrm{O}$ (99\%, SigmaAldrich, USA), $\left(\mathrm{NH}_{4}\right)_{6} \mathrm{Mo}_{7} \mathrm{O}_{24} \cdot 4 \mathrm{H}_{2} \mathrm{O}$ (99\%, Alfa Aesar, USA), $\operatorname{Er}\left(\mathrm{NO}_{3}\right)_{3} \cdot 5 \mathrm{H}_{2} \mathrm{O}$ (99.9\%, Sigma-Aldrich, USA), $\mathrm{Yb}$ $\left(\mathrm{NO}_{3}\right)_{3} \cdot 5 \mathrm{H}_{2} \mathrm{O} \quad(99.9 \%$, Sigma-Aldrich, USA), citric acid (99.5\%, Daejung Chemicals, Korea), $\mathrm{NH}_{4} \mathrm{OH}$ (A.R.), ethylene glycol (A.R.) and distilled water were used to prepare $\mathrm{SrGd}_{2}\left(\mathrm{MoO}_{4}\right)_{4}, \quad \operatorname{SrGd}_{18}\left(\mathrm{MoO}_{4}\right)_{4}: \mathrm{Er}_{0.2}, \quad \operatorname{SrGd}_{17}\left(\mathrm{MoO}_{4}\right)_{4}: \mathrm{Er}_{0.1} \mathrm{Yb}_{02}$ and $\mathrm{SrGd}_{1.5}\left(\mathrm{MoO}_{4}\right)_{4}: \mathrm{Er}_{0.05} \mathrm{Yb}_{0.45}$ compounds with doping concentrations of $\mathrm{Er}^{3+}$ and $\mathrm{Yb}^{3+}\left(\mathrm{Er}^{3+}=0.05,0.1,0.2\right.$ and $\mathrm{Yb}^{3+}=$ $0.2,0.45)$. To prepare $\mathrm{SrGd}_{2}\left(\mathrm{MoO}_{4}\right)_{4}, 0.4 \mathrm{~mol} \% \mathrm{Sr}\left(\mathrm{NO}_{3}\right)_{2} \cdot 4 \mathrm{H}_{2} \mathrm{O}$ and $0.23 \mathrm{~mol} \%\left(\mathrm{NH}_{4}\right)_{6} \mathrm{Mo}_{7} \mathrm{O}_{24} \cdot 4 \mathrm{H}_{2} \mathrm{O}$ were dissolved in $20 \mathrm{~mL}$ of ethylene glycol and $80 \mathrm{~mL}$ of $5 \mathrm{M} \mathrm{NH}_{4} \mathrm{OH}$ under vigorous stirring and heating. Subsequently, $0.8 \mathrm{~mol} \% \mathrm{Gd}\left(\mathrm{NO}_{3}\right)_{3}$. $6 \mathrm{H}_{2} \mathrm{O}$ and citric acid (with a molar ratio of citric acid to total metal ions of $2: 1$ ) were dissolved in $100 \mathrm{~mL}$ of distilled water under vigorous stirring and heating. Then, the solutions were mixed together under vigorous stirring and heating at $80-100^{\circ} \mathrm{C}$. Finally, highly transparent solutions were obtained and adjusted to $\mathrm{pH}=7-8$ by the addition of $8 \mathrm{M}$ $\mathrm{NH}_{4} \mathrm{OH}$. To prepare $\operatorname{SrGd}_{1.8}\left(\mathrm{MoO}_{4}\right)_{4}: \mathrm{Er}_{0.2}$, the mixture of $0.72 \mathrm{~mol} \% \mathrm{Sr}\left(\mathrm{NO}_{3}\right)_{3} \cdot 6 \mathrm{H}_{2} \mathrm{O}$ with $0.08 \mathrm{~mol} \% \operatorname{Er}\left(\mathrm{NO}_{3}\right)_{3} \cdot 5 \mathrm{H}_{2} \mathrm{O}$ was used for the creation of the rare earth solution. To prepare $\operatorname{SrGd}_{1.7}\left(\mathrm{MoO}_{4}\right)_{4}: \mathrm{Er}_{0.1} \mathrm{Yb}_{0.2}$, the mixture of $0.68 \mathrm{~mol} \%$ $\mathrm{Sr}\left(\mathrm{NO}_{3}\right)_{3} \cdot 6 \mathrm{H}_{2} \mathrm{O}$ with $0.04 \mathrm{~mol} \% \mathrm{Er}\left(\mathrm{NO}_{3}\right)_{3} \cdot 5 \mathrm{H}_{2} \mathrm{O}$ and $0.08 \mathrm{~mol} \%$ $\mathrm{Yb}\left(\mathrm{NO}_{3}\right)_{3} \cdot 5 \mathrm{H}_{2} \mathrm{O}$ was used for the creation of the rare earth solution. To prepare $\operatorname{SrGd}_{15}\left(\mathrm{MoO}_{4}\right)_{4}: \mathrm{Er}_{0.05} \mathrm{Yb}_{0.45}$, the rare earth containing solution was generated using $0.6 \mathrm{~mol} \% \mathrm{Gd}\left(\mathrm{NO}_{3}\right)_{3} \cdot 6 \mathrm{H}_{2} \mathrm{O}$ with $0.02 \mathrm{~mol} \% \mathrm{Er}\left(\mathrm{NO}_{3}\right)_{3} \cdot 5 \mathrm{H}_{2} \mathrm{O}$ and $0.18 \mathrm{~mol} \% \mathrm{Yb}\left(\mathrm{NO}_{3}\right)_{3} \cdot 5 \mathrm{H}_{2} \mathrm{O}$.
The transparent solutions were placed in a microwave oven operating at a frequency of $2.45 \mathrm{GHz}$ with a maximum output-power of $1250 \mathrm{~W}$ for $30 \mathrm{~min}$. The working cycle of the microwave reaction was controlled very precisely using a regime of $40 \mathrm{~s}$ on and $20 \mathrm{~s}$ off for $15 \mathrm{~min}$, followed by further treatment of $30 \mathrm{~s}$ on and $30 \mathrm{~s}$ off for $15 \mathrm{~min}$. The samples were treated with ultrasonic radiation for $10 \mathrm{~min}$ to produce a light yellow transparent sol. After this, the light yellow transparent sols were dried at $120^{\circ} \mathrm{C}$ in a dry oven to obtain black dried gels. The black dried gels were ground and heattreated at $900^{\circ} \mathrm{C}$ for $16 \mathrm{~h}$ with $100^{\circ} \mathrm{C}$ intervals between 600 $900^{\circ} \mathrm{C}$. Finally, white particles were obtained for $\mathrm{SrGd}_{2}$ $\left(\mathrm{MoO}_{4}\right)_{4}$ and pink particles for the $\mathrm{SrGd}_{1.8}\left(\mathrm{MoO}_{4}\right)_{4}: \mathrm{Er}_{0.2}, \mathrm{Sr}$ $\mathrm{Gd}_{1.7}\left(\mathrm{MoO}_{4}\right)_{4}: \mathrm{Er}_{0.1} \mathrm{Yb}_{0.2}$ and $\operatorname{SrGd}_{1.5}\left(\mathrm{MoO}_{4}\right)_{4}: \mathrm{Er}_{0.05} \mathrm{Yb}_{0.45}$ compositions.

The phase composition of the synthesized particles was identified using XRD (D/MAX 2200, Rigaku, Japan). The microstructure and surface morphology of the $\mathrm{SrGd}_{2}$ $\left(\mathrm{MoO}_{4}\right)_{4}, \operatorname{SrGd}_{18}\left(\mathrm{MoO}_{4}\right)_{4}: \mathrm{Er}_{02}, \operatorname{SrGd}_{17}\left(\mathrm{MoO}_{4}\right)_{4}: \mathrm{Er}_{0.1} \mathrm{Yb}_{02}$ and $\mathrm{Sr}$ $\mathrm{Gd}_{1.5}\left(\mathrm{MoO}_{4}\right)_{4}: \mathrm{Er}_{0.05} \mathrm{Yb}_{0.45}$ particles were observed using SEM/ EDS (JSM-5600, JEOL, Japan). The PL spectra were recorded using a spectrophotometer (Perkin Elmer LS55, UK) at room temperature. Raman spectroscopy measurements were performed using a LabRam Aramis (Horiba Jobin-Yvon, France). The 514.5-nm line of an Ar ion laser was used as the excitation source, and the power on the samples was kept at $0.5 \mathrm{~mW}$.

\section{Results and Discussion}

Figure 1 shows the XRD patterns of the (a) JCPDS 080482 data of $\mathrm{SrMoO}_{4}$, the synthesized (b) $\mathrm{SrGd}_{2}\left(\mathrm{MoO}_{4}\right)_{4}$, (c) $\operatorname{SrGd}_{1.8}\left(\mathrm{MoO}_{4}\right)_{4}: \mathrm{Er}_{0.2}$, (d) $\operatorname{SrGd}_{1.7}\left(\mathrm{MoO}_{4}\right)_{4}: \mathrm{Er}_{0.1} \mathrm{Yb}_{0.2}$, and (e) $\operatorname{SrGd}_{1.5}$ $\left(\mathrm{MoO}_{4}\right)_{4}: \mathrm{Er}_{0.05} \mathrm{Yb}_{0.45}$ particles. All of the XRD peaks could be assigned to the tetragonal-phase $\mathrm{SrMoO}_{4}$ with a scheelitetype structure of space group I $4_{1 /}$ a with lattice parameters

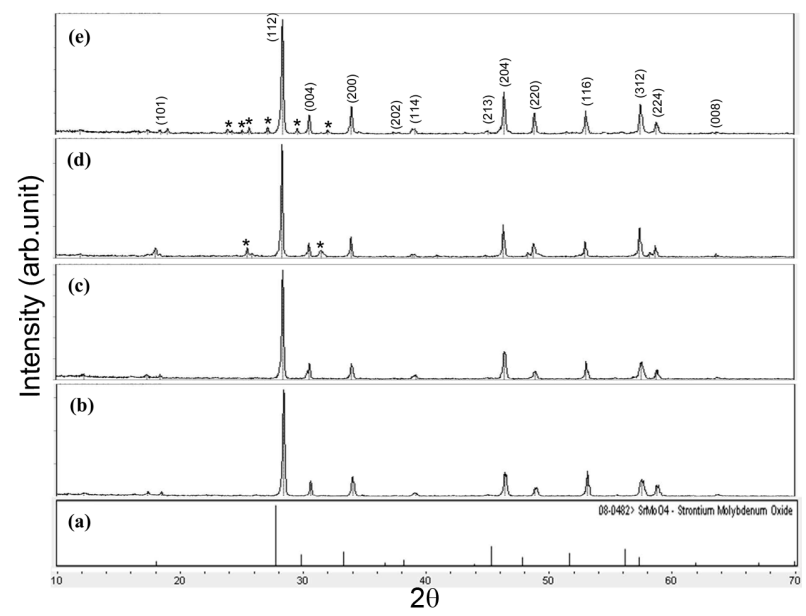

Fig. 1. X-ray diffraction patterns of the (a) JCPDS 08-0482 data of $\mathrm{SrMoO}_{4}$, the synthesized (b) $\mathrm{SrGd}_{2}\left(\mathrm{MoO}_{4}\right)_{4}$, (c) $\mathrm{SrGd}_{1.8}\left(\mathrm{MoO}_{4}\right)_{4}: \mathrm{Er}_{0.2}$, (d) $\mathrm{SrGd}_{1.7}\left(\mathrm{MoO}_{4}\right)_{4}: \mathrm{Er}_{0.1} \mathrm{Yb}_{0.2}$, and (e) $\operatorname{SrGd}_{1.5}\left(\mathrm{MoO}_{4}\right)_{4}: \operatorname{Er}_{0.05} \mathrm{Yb}_{0.45}$ particles. 


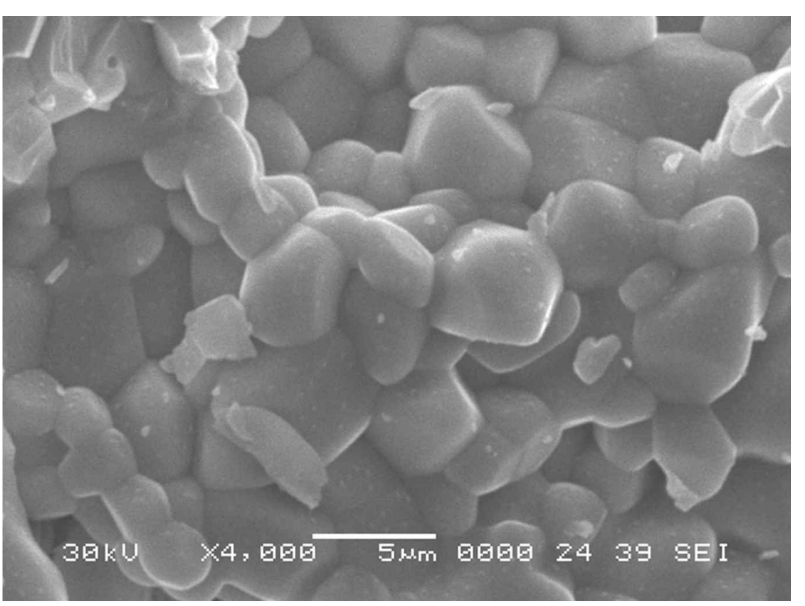

Fig. 2. Scanning electron microscopy image of the synthesized $\operatorname{SrGd}_{1.5}\left(\mathrm{MoO}_{4}\right)_{4}: \mathrm{Er}_{0.05} \mathrm{Yb}_{0.45}$ particles.

of $\mathrm{a}=\mathrm{b}=5.3796 \AA$ and $\mathrm{c}=11.9897 \AA{ }^{23-25)}$ which was in good agreement with the crystallographic data of $\mathrm{SrMoO}_{4}$ (JCPDS 08-0482). This means that the tetragonal-phase of $\mathrm{SrGd}_{2}\left(\mathrm{MoO}_{4}\right)_{4}: \mathrm{Er}^{3+} / \mathrm{Yb}^{3+}$ can be prepared using the cyclic microwave-modified sol-gel method. During the cyclic microwave-modified sol-gel process, the ethylene glycol was evaporated slowly at its boiling point. Ethylene glycol is a polar solvent at its boiling point of $197^{\circ} \mathrm{C}$, and this solvent is a good candidate for the microwave process. If ethylene glycol is used as the solvent, the reactions proceed at the boiling point temperature. When microwave radiation is applied to the ethylene-glycol-based solution, the components dissolved in the ethylene glycol can couple. The charged particles vibrate in the electric field interdependently when a large amount of microwave radiation is applied to the ethylene glycol. This suggests that the cyclic microwave-modified sol-gel route is suitable for the growth of $\mathrm{SrGd}_{2}\left(\mathrm{MoO}_{4}\right)_{4}: \mathrm{Er}^{3+} / \mathrm{Yb}^{3+}$ crystallites and for developing the strongest intensity peaks at the (112), (204), and (312) planes, which are the major peaks of $\mathrm{SrMoO}_{4}{ }^{23-25)}$ Impurity phases were detected at $25^{\circ}$ and $31.5^{\circ}$ in Fig. $1(\mathrm{~d})$ and at $24^{\circ}$, $25^{\circ}, 25.5^{\circ}, 29.5^{\circ}$, and $32^{\circ}$ in Fig. 1(e). The foreign reflexes are marked with asterisk in Fig. 1(d) when the doping concentration of $\mathrm{Er}^{3+} / \mathrm{Yb}^{3+}$ is $0.04 / 008 \mathrm{~mol} \%$ and in Fig. 1(e) when the doping concentration of $\mathrm{Er}^{3+} / \mathrm{Yb}^{3+}$ is $0.02 / 0.18$ mol\%. However, it is difficult to identify the impurity phases since very weak peaks are observed. A similar impurity phase is also observed in the case of $\mathrm{Er}^{3+} / \mathrm{Yb}^{3+}$-doped $\mathrm{SrMoO}_{4}$ phosphor when the doping concentration of $\mathrm{Er}^{3+} /$ $\mathrm{Yb}^{3+}$ is $0.02 / 0.18 \mathrm{~mol} \%{ }^{26)}$ Post heat-treatment plays an important role in a well-defined crystallized morphology. To achieve a well-defined crystalline morphology, the $\mathrm{SrGd}_{2}\left(\mathrm{MoO}_{4}\right)_{4}: \mathrm{Er}^{3+} / \mathrm{Yb}^{3+}$ phases need to be heat treated at $900^{\circ} \mathrm{C}$ for $12 \mathrm{~h}$. It is assumed that the doping amount of $\mathrm{Er}^{3+} / \mathrm{Yb}^{3+}$ has a great effect on the crystalline cell volume of the $\operatorname{SrGd}_{2}\left(\mathrm{MoO}_{4}\right)_{4}$, because of the different ionic sizes and energy band gaps. This means that the obtained samples have a tetragonal-phase after partial substitution of $\mathrm{Gd}^{3+}$ by
$\mathrm{Er}^{3+}$ and $\mathrm{Yb}^{3+}$ ions, and the ions are effectively doped into crystal lattices of the $\operatorname{SrGd}_{2}\left(\mathrm{MoO}_{4}\right)_{4}$ phase due to the similar radii of $\mathrm{Gd}^{3+}$ and by $\mathrm{Er}^{3+}$ and $\mathrm{Yb}^{3+}$. 4 )

Figure 2 shows a scanning electron microscopy image of the synthesized $\operatorname{SrGd}_{1.5}\left(\mathrm{MoO}_{4}\right)_{4}: \mathrm{Er}_{0.05} \mathrm{Yb}_{0.45}$ particles. The assynthesized samples are well crystallized with a fine and homogeneous morphology and grain sizes of 2-5 $\mu \mathrm{m}$. Fig. 3 shows the energy-dispersive X-ray spectroscopy patterns of the synthesized (a) $\operatorname{SrGd}_{1.8}\left(\mathrm{MoO}_{4}\right)_{4}: \mathrm{Er}_{0.2}$ and (b) $\mathrm{SrGd}_{1.5}$ $\left(\mathrm{MoO}_{4}\right)_{4}: \mathrm{Er}_{0.05} \mathrm{Yb}_{0.45}$ particles, and quantitative compositions of (c) $\mathrm{SrGd}_{1.8}\left(\mathrm{MoO}_{4}\right)_{4}: \mathrm{Er}_{0.2}$ and (d) $\operatorname{SrGd}_{1.5}\left(\mathrm{MoO}_{4}\right)_{4}: \mathrm{Er}_{0.05} \mathrm{Yb}_{0.45}$ particles. The EDS pattern shows that the (a) $\mathrm{SrGd}_{1.8}$ $\left(\mathrm{MoO}_{4}\right)_{4}: \mathrm{Er}_{0.2}$ and (b) $\operatorname{SrGd}_{1.5}\left(\mathrm{MoO}_{4}\right)_{4}: \mathrm{Er}_{0.05} \mathrm{Yb}_{0.45}$ particles are composed of $\mathrm{Sr}, \mathrm{Gd}, \mathrm{Mo}, \mathrm{O}$ and $\mathrm{Er}$ for $\mathrm{SrGd}_{2}\left(\mathrm{MoO}_{4}\right)_{4}: \mathrm{Er}^{3+}$ and $\mathrm{Sr}, \mathrm{Gd}, \mathrm{Mo}, \mathrm{O}$ Er and $\mathrm{Yb}$ for $\mathrm{SrGd}_{1.5}\left(\mathrm{MoO}_{4}\right)_{4}: \mathrm{Er}_{0.05} \mathrm{Yb}_{0.45}$ particles. The quantitative compositions (c) and (d) are in good relation with nominal compositions of the $\operatorname{SrGd}_{1.8}\left(\mathrm{MoO}_{4}\right)_{4}$ : $\mathrm{Er}_{0.2}$ and $\mathrm{SrGd}_{1.5}\left(\mathrm{MoO}_{4}\right)_{4}: \mathrm{Er}_{0.05} \mathrm{Yb}_{0.45}$ particles. The relation of $\mathrm{Sr}, \mathrm{Gd}, \mathrm{Mo}, \mathrm{O} \mathrm{Er}$ and $\mathrm{Yb}$ components exhibits that $\operatorname{SrGd}_{1.8}\left(\mathrm{MoO}_{4}\right)_{4}: \mathrm{Er}_{0.2}$ and $\mathrm{SrGd}_{1.5}\left(\mathrm{MoO}_{4}\right)_{4}: \mathrm{Er}_{0.05} \mathrm{Yb}_{0.45}$ particles can be successfully synthesized using the cyclic microwavemodified sol-gel method. The cyclic microwave-modified solgel process of double molybdates provides the energy to synthesize the bulk of the material uniformly, so that fine particles with controlled morphology can be fabricated in short time periods. The method is a cost-effective way to provide highly homogeneous products with easy scale-up, and it is a viable alternative for the rapid synthesis of UC particles.

Figure 4 shows the UC photoluminescence emission spectra of the as-prepared (a) $\operatorname{SrGd}_{2}\left(\mathrm{MoO}_{4}\right)_{4}$, (b) $\operatorname{SrGd}_{18}\left(\mathrm{MoO}_{4}\right)_{4}$ : $\operatorname{Er}_{0.2}$, (c) $\operatorname{SrGd}_{1.7}\left(\mathrm{MoO}_{4}\right)_{4}: \operatorname{Er}_{0.1} \mathrm{Yb}_{0.2}$ and (d) $\operatorname{SrGd}_{1.5}\left(\mathrm{MoO}_{4}\right)_{4}$ : $\mathrm{Er}_{0.05} \mathrm{Yb}_{0.45}$ particles excited under $980 \mathrm{~nm}$ at room temperature. The $\operatorname{SrGd}_{1.7}\left(\mathrm{MoO}_{4}\right)_{4}: \mathrm{Er}_{0.1} \mathrm{Yb}_{0.2}$ and $\operatorname{SrGd}_{1.5}\left(\mathrm{MoO}_{4}\right)_{4}: \mathrm{Er}_{0.05}$ $\mathrm{Yb}_{0.45}$ particles exhibit strong 525-nm and 550-nm emission bands in the green region, which correspond to the ${ }^{2} \mathrm{H}_{11 / 2} \rightarrow$ ${ }^{4} \mathrm{I}_{15 / 2}$ and ${ }^{4} \mathrm{~S}_{3 / 2} \rightarrow{ }^{4} \mathrm{I}_{15 / 2}$ transitions, respectively, while the very weak $655-\mathrm{nm}$ emission band in the red region corresponds to the ${ }^{4} \mathrm{~F}_{9 / 2} \rightarrow{ }^{4} \mathrm{I}_{15 / 2}$ transition. The UC intensities of (a) $\mathrm{SrGd}_{2}\left(\mathrm{MoO}_{4}\right)_{4}$ and (b) $\operatorname{SrGd}_{1.8}\left(\mathrm{MoO}_{4}\right)_{4}: \mathrm{Er}_{0.2}$ were not detected. The UC intensity of (d) $\operatorname{SrGd}_{1.5}\left(\mathrm{MoO}_{4}\right): \mathrm{Er}_{0.05} \mathrm{Yb}_{0.45}$ is much higher than that of (c) $\operatorname{SrGd}_{1.7}\left(\mathrm{MoO}_{4}\right)_{4}: \mathrm{Er}_{0.1} \mathrm{Yb}_{0.2}$ particles. Similar results are also observed from $\mathrm{Er}^{3+} / \mathrm{Yb}^{3+}$ codoped in other host matrices, which are assigned in the UC emission spectra with the green emission intensity $\left({ }^{2} \mathrm{H}_{11 / 2} \rightarrow\right.$ ${ }^{4} \mathrm{I}_{15 / 2}$ and ${ }^{4} \mathrm{~S}_{3 / 2} \rightarrow{ }^{4} \mathrm{I}_{15 / 2}$ transitions) and the red emission intensity $\left({ }^{4} \mathrm{~F}_{9 / 2} \rightarrow{ }^{4} \mathrm{I}_{15 / 2}\right.$ transition). ${ }^{7,10,18,27)}$

Figure 5 shows schematic energy level diagrams of $\operatorname{Er}^{3+}$ ions (activator) and $\mathrm{Yb}^{3+}$ ions (sensitizer) in the as-prepared $\mathrm{SrGd}_{2}\left(\mathrm{MoO}_{4}\right)_{4}: \mathrm{Er}^{3+} / \mathrm{Yb}^{3+}$ system and the upconversion mechanisms accounting for the green and red emissions under 980-nm laser excitation. For $\mathrm{Er}^{3+} / \mathrm{Yb}^{3+}$ co-doped UC phosphors, the $\mathrm{Yb}^{3+}$ ion sensitizer can be effectively excited by the energy of the incident light source, which transfers this energy to the activator, where radiation can be emitted. The $\mathrm{Er}^{3+}$ ion activator is the luminescence center in UC particles, and the sensitizer enhances the UC luminescence efficiency 


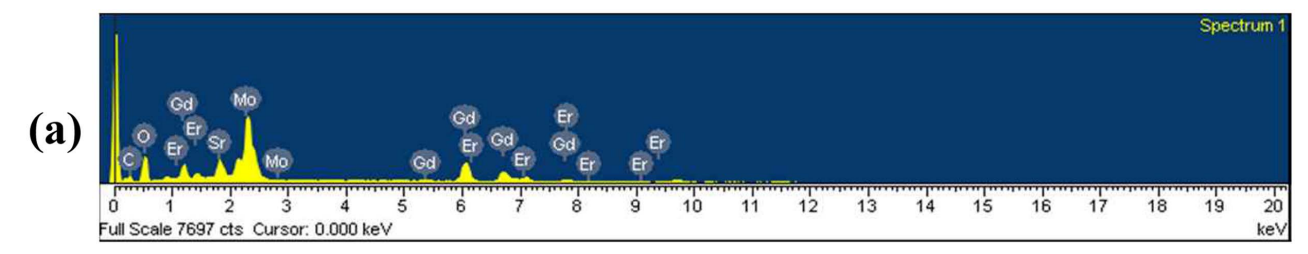

(b)

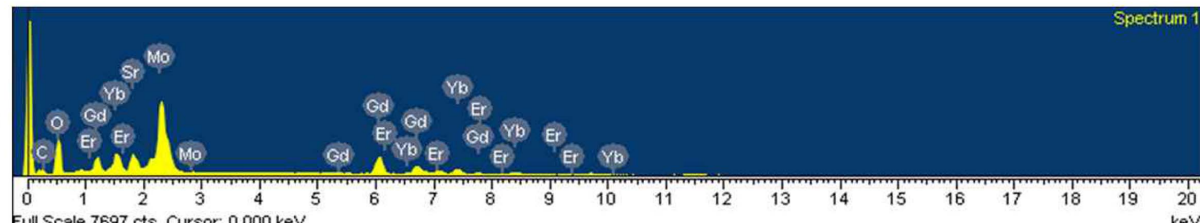
Full Scale $7697 \mathrm{cts}$ Cursor: $0.000 \mathrm{keV}$

\begin{tabular}{|c|c|c|c|c|c|c|c|c|c|}
\hline Spectrum & In stats. & C & $\mathrm{O}$ & $\mathrm{Sr}$ & Mo & $\mathrm{Gd}$ & $\mathrm{Er}$ & \multicolumn{2}{|c|}{ Total } \\
\hline Spectrum 1 & Yes & 12.75 & 33.34 & 5.55 & 26.71 & 19.60 & 2.05 & \multicolumn{2}{|c|}{100.00} \\
\hline Spectrum 2 & Yes & 13.41 & 32.78 & 5.30 & 26.57 & 19.00 & 2.95 & \multicolumn{2}{|c|}{100.00} \\
\hline Spectrum 3 & Yes & 11.76 & 33.20 & 5.29 & 27.30 & 19.60 & 2.85 & \multicolumn{2}{|c|}{100.00} \\
\hline Spectrum 4 & Yes & 11.03 & 33.39 & 5.30 & 27.63 & 20.24 & 2.42 & \multicolumn{2}{|c|}{100.00} \\
\hline Spectrum 5 & Yes & 11.61 & 33.23 & 5.08 & 27.85 & 19.65 & 2.58 & \multicolumn{2}{|c|}{100.00} \\
\hline Mean & & 12.11 & 33.18 & 5.31 & 27.21 & 19.62 & 2.57 & \multicolumn{2}{|c|}{100.00} \\
\hline Std. deviation & & 0.95 & 0.24 & 0.17 & 0.56 & 0.44 & 0.36 & & \\
\hline Max. & & 13.41 & 33.39 & 5.55 & 27.85 & 20.24 & 2.95 & & \\
\hline Min. & & 11.03 & 32.78 & 5.08 & 26.57 & 19.00 & 2.05 & & \\
\hline Spectrum & In stats. & $C$ & 0 & $\mathrm{Sr}$ & Mo & $\mathrm{Gd}$ & $\mathrm{Er}$ & $\mathrm{Yb}$ & Total \\
\hline Spectrum 1 & Yes & 7.55 & 37.71 & 4.77 & 26.76 & 15.26 & 0.62 & 7.31 & 100.00 \\
\hline Spectrum 2 & Yes & 4.66 & 39.08 & 4.79 & 28.23 & 15.41 & 0.48 & 7.34 & 100.00 \\
\hline Spectrum 3 & Yes & 2.38 & 39.52 & 5.23 & 28.54 & 16.06 & 0.95 & 7.32 & 100.00 \\
\hline Spectrum 4 & Yes & 7.74 & 37.45 & 4.54 & 27.29 & 15.17 & 0.63 & 7.18 & 100.00 \\
\hline Spectrum 5 & Yes & 7.69 & 37.67 & 4.63 & 27.08 & 14.93 & 0.62 & 7.39 & 100.00 \\
\hline Mean & & 6.01 & 38.29 & 4.79 & 27.58 & 15.37 & 0.66 & 7.31 & 100.00 \\
\hline Std. deviation & & 2.40 & 0.94 & 0.27 & 0.76 & 0.43 & 0.17 & 0.08 & \\
\hline Max. & & 7.74 & 39.52 & 5.23 & 28.54 & 16.06 & 0.95 & 7.39 & \\
\hline Min. & & 2.38 & 37.45 & 4.54 & 26.76 & 14.93 & 0.48 & 7.18 & \\
\hline
\end{tabular}

Fig. 3. Energy-dispersive X-ray spectroscopy patterns of the synthesized (a) $\operatorname{SrGd}_{1.8}\left(\mathrm{MoO}_{4}\right)_{4}: \operatorname{Er}_{0.2}$ and $(\mathrm{b}) \mathrm{SrGd}_{1.5}\left(\mathrm{MoO}_{4}\right)_{4}: \mathrm{Er}_{0.05} \mathrm{Yb}_{0.45}$ particles and quantitative compositions of (c) $\operatorname{SrGd}_{1.8}\left(\mathrm{MoO}_{4}\right)_{4}: \mathrm{Er}_{0.2}$ and (d) $\operatorname{SrGd}_{1.5}\left(\mathrm{MoO}_{4}\right)_{4}: \mathrm{Er}_{0.05} \mathrm{Yb}_{0.45}$ particles.

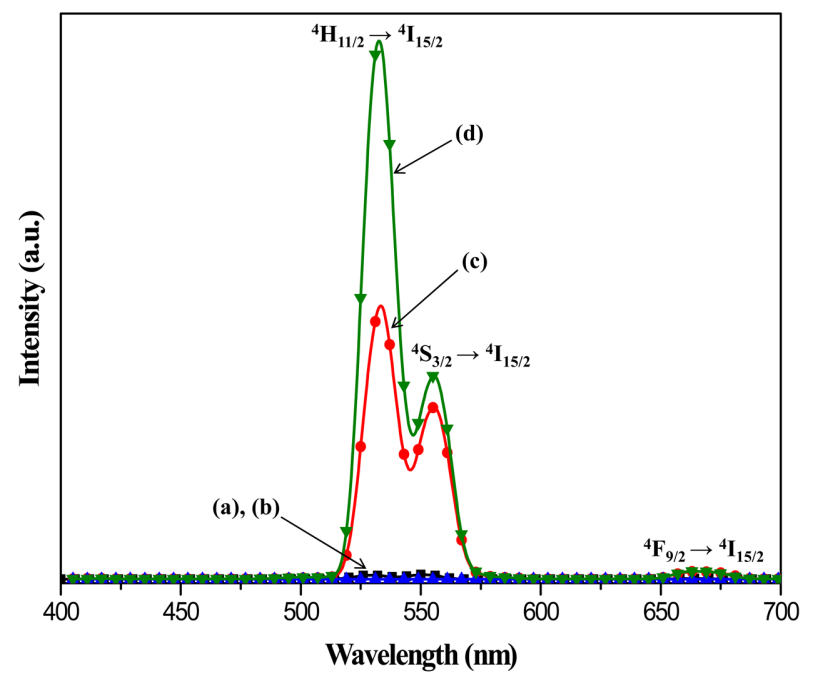

Fig. 4. Upconversion photoluminescence emission spectra of (a) $\mathrm{SrGd}_{2}\left(\mathrm{MoO}_{4}\right)_{4}$, (b) $\mathrm{SrGd}_{18}\left(\mathrm{MoO}_{4}\right)_{4}: \mathrm{Er}_{02}$, (c) $\mathrm{SrGd}_{17}$ $\left(\mathrm{MoO}_{4}\right)_{4}: \mathrm{Er}_{0.1} \mathrm{Yb}_{0.2}$ and (d) $\operatorname{SrGd}_{1.5}\left(\mathrm{MoO}_{4}\right)_{4}: \mathrm{Er}_{0.05} \mathrm{Yb}_{0.45}$ particles excited under $980 \mathrm{~nm}$ at room temperature.

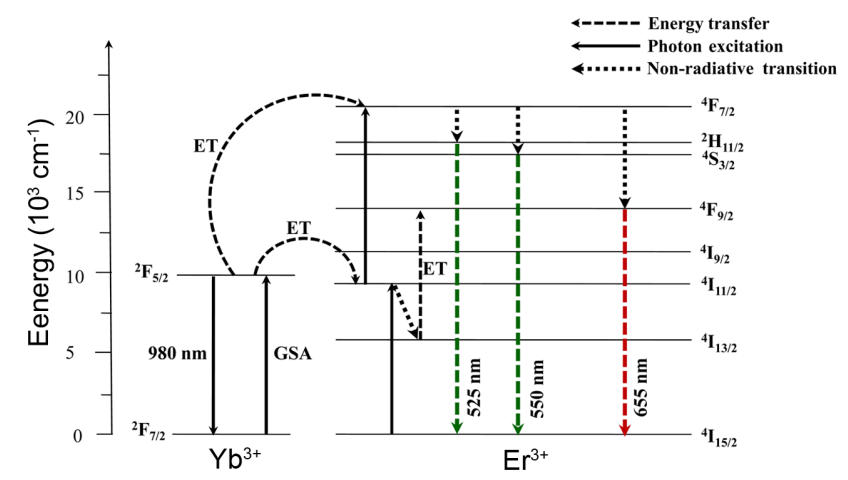

Fig. 5. Schematic energy level diagrams of $\mathrm{Er}^{3+}$ ions (activator) and $\mathrm{Yb}^{3+}$ ions (sensitizer) in the as-prepared $\mathrm{SrGd}_{2}\left(\mathrm{MoO}_{4}\right)_{4}: \mathrm{Er}^{3+} / \mathrm{Yb}^{3+}$ system and the upconversion mechanisms accounting for the green and red emissions under $980 \mathrm{~nm}$ laser excitation. 


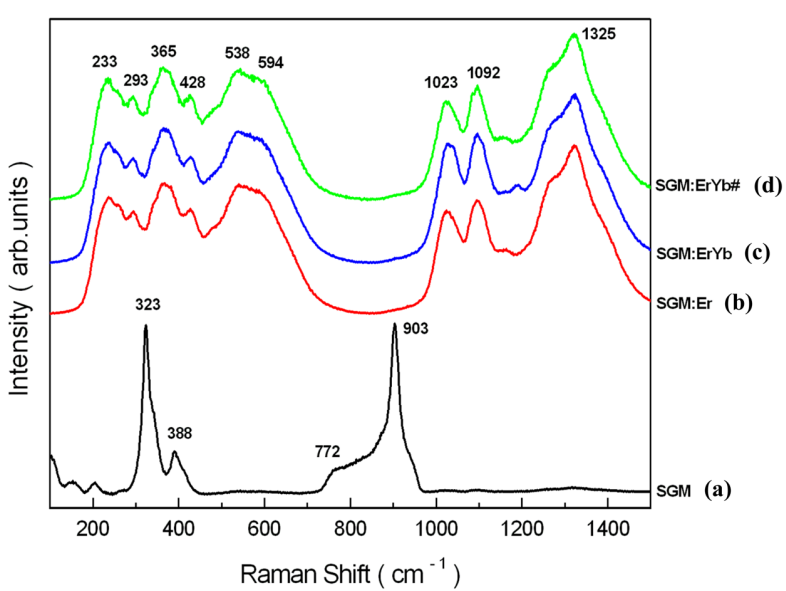

Fig. 6. Raman spectra of the synthesized (a) $\mathrm{SrGd}_{2}\left(\mathrm{MoO}_{4}\right)_{4}$ (SGM), (b) $\operatorname{SrGd}_{18}\left(\mathrm{MoO}_{4}\right)_{4}: \mathrm{Er}_{02}$ (SGM:Er), (c) $\mathrm{SrGd}_{1.7}$ $\left(\mathrm{MoO}_{4}\right)_{4}: \mathrm{Er}_{0.1} \mathrm{Yb}_{0.2}$ (SGM:ErYb) and (d) $\mathrm{SrGd}_{1.5}\left(\mathrm{MoO}_{4}\right)_{4}$ : $\mathrm{Er}_{0.05} \mathrm{Yb}_{0.45}$ (SGM:ErYb\#) particles excited by the $514.5 \mathrm{~nm}$ line of an Ar ion laser at $0.5 \mathrm{~mW}$ on the samples.

due to the energy matching of the gap between the ${ }^{2} \mathrm{~F}_{7 / 2}$ and the ${ }^{2} \mathrm{~F}_{5 / 2}$ of $\mathrm{Yb}^{3+}$. The UC emissions are generated through multiple processes of ground-state absorption (GSA) and energy transfer (ET). For the green emissions, under the excitation of $980 \mathrm{~nm}$, the $\mathrm{Yb}^{3+}$ ion sensitizer is excited from the ground state of the ${ }^{2} \mathrm{~F}_{7 / 2}$ to the excited state of the ${ }^{2} \mathrm{~F}_{5 / 2}$ through the GSA process, and the energy is transferred to the excited $\mathrm{Er}^{3+}$ ions and promoted from the ${ }^{4} \mathrm{I}_{15 / 2}$ to the ${ }^{4} \mathrm{I}_{11 / 2}$ by the ET process of ${ }^{4} \mathrm{I}_{15 / 2}\left(\mathrm{Er}^{3+}\right)+{ }^{2} \mathrm{~F}_{5 / 2}\left(\mathrm{Yb}^{3+}\right) \rightarrow{ }^{4} \mathrm{I}_{11 / 2}\left(\mathrm{Er}^{3+}\right)+$ ${ }^{2} \mathrm{~F}_{7 / 2}\left(\mathrm{Yb}^{3+}\right)$. Another $\mathrm{Yb}^{3+}$ ion at the ${ }^{2} \mathrm{~F}_{5 / 2}$ level transfers the energy to the excited $\mathrm{Er}^{3+}$ ion, and then further transits the energy from the ${ }^{4} \mathrm{I}_{11 / 2}$ to the higher ${ }^{2} \mathrm{~F}_{7 / 2}$ level by another ET process of ${ }^{4} \mathrm{I}_{11 / 2}\left(\mathrm{Er}^{3+}\right)+{ }^{2} \mathrm{~F}_{5 / 2}\left(\mathrm{Yb}^{3+}\right) \rightarrow{ }^{4} \mathrm{~F}_{7 / 2}\left(\mathrm{Er}^{3+}\right)+{ }^{2} \mathrm{~F}_{7 / 2}\left(\mathrm{Yb}^{3+}\right)$, which are for the population of the different level in $\mathrm{Er}^{3+}$. The populated ${ }^{4} \mathrm{~F}_{7 / 2}$ level relaxes rapidly and non-radiatively to the next lower ${ }^{2} \mathrm{H}_{11 / 2}$ and ${ }^{4} \mathrm{~S}_{3 / 2}$ in $\mathrm{Er}^{3+}$ because of the short lifetime of the ${ }^{4} \mathrm{~F}_{7 / 2}$ level. Then, the radiative transitions of ${ }^{2} \mathrm{H}_{11 / 2} \rightarrow{ }^{4} \mathrm{I}_{15 / 2}$ and ${ }^{4} \mathrm{~S}_{3 / 2} \rightarrow{ }^{4} \mathrm{I}_{15 / 2}$ processes can produce green emission at 525 and $550 \mathrm{~nm}$, respectively. It is noted that the green upconversion luminescence can be induced by a two-photon process. ${ }^{10,28)}$ For red emission, the ${ }^{4} \mathrm{~F}_{9 / 2}$ level is populated by non-radiative relaxation from the ${ }^{4} \mathrm{~S}_{3 / 2}$ to the ${ }^{4} \mathrm{~F}_{9 / 2}$ level and the second ET from the ${ }^{4} \mathrm{I}_{13 / 2}$ to the ${ }^{4} \mathrm{~F}_{9 / 2}$ level in $\mathrm{Er}^{3+}$. Finally, the ${ }^{4} \mathrm{~F}_{9 / 2}$ level relaxes radiatively to the ground state at the ${ }^{4} \mathrm{I}_{15 / 2}$ level and releases red emission at 655 $\mathrm{nm} .{ }^{29)}$ The strong 525-nm and 550-nm emission bands in the green region as shown in Fig. 4 are assigned to the ${ }^{2} \mathrm{H}_{11 / 2} \rightarrow$ ${ }^{4} \mathrm{I}_{15 / 2}$ and ${ }^{4} \mathrm{~S}_{3 / 2} \rightarrow{ }^{4} \mathrm{I}_{15 / 2}$ transitions of $\mathrm{Er}^{3+}$ ions, respectively, while the weak 655-nm emission band in the red region is assigned to the ${ }^{4} \mathrm{~F}_{9 / 2} \rightarrow{ }^{4} \mathrm{I}_{15 / 2}$ transition. The much higher intensity of the ${ }^{2} \mathrm{H}_{11 / 2} \rightarrow{ }^{4} \mathrm{I}_{15 / 2}$ transition in comparison with that of the ${ }^{4} \mathrm{~S}_{3 / 2} \rightarrow{ }^{4} \mathrm{I}_{15 / 2}$ transition in Fig. 4 may be induced by the concentration quenching effect of the energy transfer between the nearest $\mathrm{Er}^{3+}$ and $\mathrm{Yb}^{3+}$ ions and the interactions between doping ions in the $\operatorname{SrGd}_{2}\left(\mathrm{MoO}_{4}\right)_{4}$ host matrix. ${ }^{7,29)}$
This means that the green band ${ }^{2} \mathrm{H}_{11 / 2} \rightarrow{ }^{4} \mathrm{I}_{15 / 2}$ transitions are assumed to be more easily quenched than that of the ${ }^{4} \mathrm{~S}_{3 / 2} \rightarrow$ ${ }^{4} \mathrm{I}_{15 / 2}$ transition by non-radiative relaxation in the case of the $\mathrm{SrGd}_{2}\left(\mathrm{MoO}_{4}\right)_{4}$ host matrix.

Fig. 6 shows the Raman spectra of the synthesized (a) $\mathrm{SrGd}_{2}\left(\mathrm{MoO}_{4}\right)_{4}(\mathrm{SGM}),(\mathrm{b}) \mathrm{SrGd}_{1.8}\left(\mathrm{MoO}_{4}\right)_{4}: \mathrm{Er}_{0.2}$ (SGM:Er), (c) $\operatorname{SrGd}_{1.7}\left(\mathrm{MoO}_{4}\right)_{4}: \mathrm{Er}_{0.1} \mathrm{Yb}_{0.2}(\mathrm{SGM}: \mathrm{ErYb})$ and (d) $\operatorname{SrGd}_{1.5}\left(\mathrm{MoO}_{4}\right)_{4}$ : $\mathrm{Er}_{0.05} \mathrm{Yb}_{0.45}$ (SGM:ErYb\#) particles excited by the 514.5-nm line of an Ar ion laser at $0.5 \mathrm{~mW}$ on the samples. The wellresolved sharp peaks for the $\mathrm{SrGd}_{2}\left(\mathrm{MoO}_{4}\right)_{4}$ particles in Fig. 6(a) indicate the high crystallization state of the synthesized particles. The internal vibration mode frequencies are dependent on the lattice parameters and the degree of the partially covalent bond between the cation and molecular ionic group $\left[\mathrm{MoO}_{4}\right]^{2-}$. The Raman spectra of the doped particles in Fig. 6(b), (c), and (d) indicate the domination of strong peaks at higher frequencies of 1023, 1092, and $1325 \mathrm{~cm}^{-1}$ and at lower frequencies of $233,293,365,428$, 538 , and $594 \mathrm{~cm}^{-1}$. In the crystal structure of $\operatorname{SrGd}_{2}\left(\mathrm{MoO}_{4}\right)_{4}$, the $\mathrm{Sr}$ ion site is supposed to be occupied by $\mathrm{Sr}^{2+}, \mathrm{Gd}^{3+}, \mathrm{Er}^{3+}$, $\mathrm{Yb}^{3+}$ ions with fixed occupations according to the nominal chemical formulas. The defined crystal structure contains $\left[\mathrm{MoO}_{4}\right]^{2-}$ tetrahedrons coordinated by four ( $\left.\mathrm{Sr} / \mathrm{Gd} / \mathrm{Er} / \mathrm{Yb}\right) \mathrm{O}_{8}$ square antiprisms through the common $\mathrm{O}$ ions. In the doped crystals, the cell volume decreases proportionally to the dopant concentration $x$ and dependence. The dependence was generated by the difference of effective ion radii $\mathrm{R}\left(\mathrm{Yb}^{3+}, \mathrm{CN}=8\right)$ $=0.985 \AA, \mathrm{R}\left(\mathrm{Er}^{3+}, \mathrm{CN}=8\right)=1.004 \AA, \mathrm{R}\left(\mathrm{Gd}^{3+}, \mathrm{CN}=8\right)=$ $1.053 \AA$. The unit cell shrinkage results from the substitution of $\mathrm{Gd}^{3+}$ ions by $\mathrm{Er}^{3+}$ and $\mathrm{Yb}^{3+}$ ions. Therefore, the strong peaks at higher and lower frequencies are attributed to the formation of disordered structures of $\mathrm{SrGd}_{2-\mathrm{x}}\left(\mathrm{MoO}_{4}\right)_{4}$ by the incorporation of the $\mathrm{Er}^{3+}$ and $\mathrm{Yb}^{3+}$ elements into the crystal lattice, resulting in the unit cell shrinkage accompanying the new phase formation of the $\left[\mathrm{MoO}_{4}\right]^{2-}$ groups. The $\left[\mathrm{MoO}_{4}\right]^{2-}$ group has strong absorption in the near ultraviolet region, so the energy transfers process from the $\left[\mathrm{MoO}_{4}\right]^{2-}$ group to rare earth ions can easily occur, which can greatly enhance the external quantum efficiency of rare earth ionsdoped materials. It is emphasized that the unit cell shrinkage accompanying the new phase formation of the $\left[\mathrm{MoO}_{4}\right]^{2-}$ groups in the $\operatorname{SrGd}_{2-\mathrm{x}}\left(\mathrm{MoO}_{4}\right)_{4}: \mathrm{Er}^{3+} / \mathrm{Yb}^{3}$ incorporated by $\mathrm{Er}^{3+}$ and $\mathrm{Yb}^{3+}$ ions strongly affects the upconversion intensities with the doping concentrations of $\mathrm{Er}^{3+}$ and $\mathrm{Yb}^{3+}$, especially in the compositions of $\operatorname{SrGd}_{1.7}\left(\mathrm{MoO}_{4}\right)_{4}: \mathrm{Er}_{0.1} \mathrm{Yb}_{0.2}$ and $\mathrm{SrGd}_{1.5}\left(\mathrm{MoO}_{4}\right)_{4}: \mathrm{Er}_{0.05} \mathrm{Yb}_{0.45}$. These results lead to high emitting efficiency, superior thermal and chemical stability and can be considered as potentially active components in new optoelectronic devices and luminescent imaging, which overcome the current limitations in traditional photoluminescence materials.

\section{Conclusion}

$\mathrm{SrGd}_{2}\left(\mathrm{MoO}_{4}\right)_{4}: \mathrm{Er}^{3+} / \mathrm{Yb}^{3+}$ green phosphors with doping concentrations of $\mathrm{Er}^{3+}$ and $\mathrm{Yb}^{3+}$ were successfully synthesized 
by a cyclic microwave-modified sol-gel method, and the upconversion mechanisms were investigated in detail. Wellcrystallized particles, formed after heat-treatment at $900^{\circ} \mathrm{C}$ for $16 \mathrm{~h}$, showed a fine and homogeneous morphology with grain sizes of 2-5 $\mu \mathrm{m}$. Under excitation at $980 \mathrm{~nm}$, the $\operatorname{SrGd}_{1.7}\left(\mathrm{MoO}_{4}\right)_{4}: \mathrm{Er}_{0.1} \mathrm{Yb}_{0.2}$ and $\mathrm{SrGd}_{1.5}\left(\mathrm{MoO}_{4}\right)_{4}: \mathrm{Er}_{0.05} \mathrm{Yb}_{0.45}$ particles exhibited strong 525-nm 550-nm emission bands in the green region, which were assigned to the ${ }^{2} \mathrm{H}_{11 / 2} \rightarrow{ }^{4} \mathrm{I}_{15 / 2}$ and ${ }^{4} \mathrm{~S}_{3 / 2} \rightarrow{ }^{4} \mathrm{I}_{15 / 2}$ transitions, respectively, while a weak 655$\mathrm{nm}$ emission band in the red region was assigned to the ${ }^{4} \mathrm{~F}_{9 / 2} \rightarrow$ ${ }^{4} \mathrm{I}_{15 / 2}$ transition by a two-photon process. The UC intensity of the $\operatorname{SrGd}_{1.5}\left(\mathrm{MoO}_{4}\right)_{4}: \mathrm{Er}_{0.05} \mathrm{Yb}_{0.45}$ particles was much higher than that of the $\operatorname{SrGd}_{1.7}\left(\mathrm{MoO}_{4}\right)_{4}: \mathrm{Er}_{0.1} \mathrm{Yb}_{0.2}$ particles. The Raman spectra of the doped particles indicated the domination of strong peaks at higher frequencies of 1023, 1092 and $1325 \mathrm{~cm}^{-1}$ and at lower frequencies of $233,293,365,428$, 538 and $594 \mathrm{~cm}^{-1}$ induced by disordered structures of $\mathrm{SrGd}_{2}$. ${ }_{\mathrm{x}}\left(\mathrm{MoO}_{4}\right)_{4}$ due to the incorporation of the $\mathrm{Er}^{3+}$ and $\mathrm{Yb}^{3+}$ ions into the crystal lattice, which resulted in the unit cell shrinkage accompanying the new phase formation of the $\left[\mathrm{MoO}_{4}\right]^{2-}$ groups.

\section{Acknowledgment}

This study was supported by the Basic Science Research Program through the National Research Foundation of Korea (NRF) funded by the Ministry of Science, ICT \& Future Planning (2014-046024).

\section{REFERENCES}

1. M. Wang, G. Abbineni, A. Clevenger, C. Mao, and S. Xu, "Upconversion Nanoparticles: Synthesis, Surface Modification and Biological Applications," Nanomedicine: Nanotech. Biol. Med., 7 [6] 710-29 (2011).

2. A. Shalav, B. S. Richards, and M. A. Green, "Luminescent Layers for Enhanced Silicon Solar Cell Performance Upconversion," Sol. Ener. Mater. Sol. Cells, 91 [9] 829-42 (2007).

3. M. Lin, Y. Zho, S. Wang, M, Liu, Z. Duan, Y. Chen, F. Li, F. $\mathrm{Xu}$, and T. Lu, "Recent Advances in Synthesis and Surface Modification of Lanthanide-doped Upconversion Nanoparticles for Biomedical Napplications," Bio. Adv., 30 [6] 155161 (2012).

4. J. Liao, D. Zhou, B. Yang, R. Liu, Q. Zhang, and Q. Zhou, "Sol-gel Preparation and Photoluminsence Properties of $\mathrm{CaLa}_{2}\left(\mathrm{MoO}_{4}\right)_{4}: \mathrm{Eu}^{3+}$ Phosphors," J. Lumin., 134 533-38 (2013).

5. J. Sun, Y. Lan, Z. Xia, and H. Du, "Sol-gel Synthesis and Green Upconversion Luminescence in $\mathrm{BaGd}_{2}\left(\mathrm{MoO}_{4}\right)_{4}: \mathrm{Yb}^{3+}$, Er $^{3+}$ Phosphors," Opt. Mater., 33 [3] 576-581(2011).

6. C. Guo, H. K. Yang, and J. H. Jeong, "Preparation and Luminescence Properties of Phosphor $\mathrm{MGd}_{2}\left(\mathrm{MoO}_{4}\right)_{4}: \mathrm{Eu}^{3+}$ (M=Ca, Sr and Ba)," J. Lumin., 130 [8] 1390-93 (2010).

7. T. Li, C. Guo, Y. Wu, L. Li, and J. H. Jeong, "Green Upconversion Luminescence in $\mathrm{Yb}^{3+} / \mathrm{Er}^{3+}$ Co-doped $\mathrm{ALn}\left(\mathrm{MoO}_{4}\right)_{2}$ (A=Li, Na and K; La, Gd, and Y)," J. Alloys Compd., 540 107-12 (2012).
8. M. Nazarov and D. Y. Noh, "Rare Earth Double Activated Phosphors for Different Applications," J. Rare Earths, 28 [1] 1-11(2010).

9. J. Sun, W. Zhang, W. Zhang, and H. Du, "Synthesis and Two-color Emission Properties of $\mathrm{BaGd}_{2}\left(\mathrm{MoO}_{4}\right)_{4}: \mathrm{Eu}^{3+}, \mathrm{Er}^{3+}, \mathrm{Yb}^{3+}$ Phosphors," Mater. Res. Bull., 47 [3] 786-89 (2012).

10. H. Du, Y. Lan, Z. Xia, and J. Sun, "Synthesis and Upconversion Luminescence Properties of $\mathrm{Yb}^{3+}, \mathrm{Er}^{3+}$ Co-doped $\mathrm{BaGd}_{2}\left(\mathrm{MoO}_{4}\right)_{4}$ Powder," Mater. Res. Bull., 44 [8] 1660-62 (2009).

11. Z. Wang, H. Liang, M. Gong, and Q. Su, "Luminescence Investigation of $\mathrm{Eu}^{3+}$ Activated Double Molybdates Red Phosphors with Scheelite Structure," J. Alloys Compd., 432 [1-2] 308-12 (2007).

12. M. Haque and D. K. Kim, "Luminescent Properties of $\mathrm{Eu}^{3+}$ Activated Doped $\mathrm{MGd}_{2}\left(\mathrm{MoO}_{4}\right)_{4}$ Based $(\mathrm{M}=\mathrm{Ba}, \mathrm{Sr}$, and $\mathrm{Ca})$ Novel Red-emitting Phosphors," Mater. Lett., 63 793-96 (2009).

13. C. Zhao, X. Yin, F. Huang, and Y. Hang, "Synthesis and Photoluminescence Properties of High-brightened $\mathrm{Eu}^{3+}$ doped $\mathrm{M}_{2} \mathrm{Gd}_{4}\left(\mathrm{MoO}_{4}\right)_{7}(\mathrm{M}=\mathrm{Li}, \mathrm{Na})$ Red Phosphors," J. Sol. State Chem., 184 3190-94 (2011).

14. L. Qin, Y. Huang, T, Tsuboi, and H. J. Seo, "The Red-emitting Phosphors of $\mathrm{Eu}^{3+}$-activated $\mathrm{MR}_{2}\left(\mathrm{MoO}_{4}\right)_{4}(\mathrm{M}=\mathrm{Ba}, \mathrm{Sr}$, $\mathrm{Ca} ; \mathrm{R}=\mathrm{La}^{3+}, \mathrm{Gd}^{3+}, \mathrm{Y}^{3+}$ ) for Light Emitting Diodes," Mater. Res. Bull., 47 [12] 4498-502 (2012).

15. Y. L. Yang, X. M. Li, W. L. Feng, W. L. Li, and C. Y. Tao, "Co-precipitation Synthesis and Photoluminescence Properties of $\left(\mathrm{Ca}_{1-\mathrm{x} \cdot \mathrm{y}}, \mathrm{Ln}_{\mathrm{y}}\right) \mathrm{MoO}_{4}: \mathrm{xEu}^{3+}(\mathrm{Ln}=\mathrm{Y}, \mathrm{Gd})$ Red Phosphors," J. Alloys Compd., 505 239-42 (2010).

16. Y. Tian, B. Chen, B. Tian, R. Hua, J. Sun, L. Cheng, H. Zhong, X. Li, J. Zhang, Y. Zheng, T. Yu, L. Huang, and Q. Meng, "Concentration-dependent Luminescence and Energy Transfer of Flower-like $\mathrm{Y}_{2}\left(\mathrm{MoO}_{4}\right)_{3}: \mathrm{Dy}^{3+}$ Phosphor," $J$. Alloys Compd., 509 6096-102 (2011).

17. Y. Huang, L. Zhou, and Z. Tang, "Self-assembled 3D Flower-like $\mathrm{NaY}\left(\mathrm{MoO}_{4}\right)_{2}: \mathrm{Eu}^{3+}$ Microarchitectures: Hydrothermal Synthesis, Formation Mechanism and Luminescence Properties," Opt. Mater., 33 [6] 777-82 (2011).

18. Y. Tian, B. Chen, B. Tian, J. Sun, X. Li, J. Zhang, L. Cheng, H. Zhong, H. Zhong, Q. Meng, and R. Hua, "Ionic Liquidassisted Hydrothermal Synthesis of Dendrite-like $\mathrm{NaY}\left(\mathrm{MoO}_{4}\right)_{2}: \mathrm{Tb}^{3+}$," Phys. B, 407 [13] 2556-59 (2012).

19. Z. Wang, H. Liang, L. Zhou, J. Wang, M. Gong, and Q. Su, " $\mathrm{NaEu}_{0.96} \mathrm{Sm}_{0.04}\left(\mathrm{MoO}_{4}\right)_{2}$ As a Promosing Red-emitting Phosphor for LED Solid-state Lighting Prepared by the Pechini Process," J. Lumin., 128 [1] 147-54 (2008).

20. Q. Chen, L. Qin, Z. Feng, R. Ge, X. Zhao, and H. Xu, "Upconversion Luminescence of $\left.\mathrm{KGd}\left(\mathrm{MoO}_{4}\right)_{2}: \mathrm{Er}^{3+}, \mathrm{Yb}^{3+}\right)$ Powder Prepared by Pechini Method," J. Rare Earths, 29 [9] 843-48 (2011).

21. X. Shen, L. Li, F. He, X. Meng, and F. Sing, "Effects of Doped- $\mathrm{Li}^{+}$and $-\mathrm{Eu}^{3+}$ Ions Content on Structure and Luminescent Properties of $\mathrm{Li}_{\mathrm{x}} \mathrm{Sr}_{1-2 \mathrm{x}}\left(\mathrm{MoO}_{4}\right) ; \mathrm{Eu}^{3+}{ }_{\mathrm{x}}$ Red-emitting Phosphors for White LEDs," Mater. Chem. Phys., 132 [2-3] 471-75 (2012).

22. J. Zhang, X. Wang, X, Zhang, X. Zhao, X. Liu, and L. Peng, "Microwave Synthesis of NaLa $\left(\mathrm{MoO}_{4}\right)_{2}$ Microcrystals and Their Near-infraed Luminescent Properties with Lantha- 
nide Ion Doping $\left(\mathrm{Er}^{3+}, \mathrm{Nd}^{3+}, \mathrm{Yb}^{3+}\right)$," Inog. Chem. Comm., 14 [11] 1723-27 (2011).

23. S. Das, A. K. Mukhopadhyay, S. Datta, and D. Basu, "Prospects of Microwave Processing: An Overview," Bull. Mater. Sci., 32 1-13 (2009).

24. T. Thongtem, A. Phuruangrat, and S. Thongtem, "Microwave-assisted Synthesis and Characterization of $\mathrm{SrMoO}_{4}$ and $\mathrm{SrWO}_{4}$ Nanocrystals," J. Nanopart. Res., 12 [6] 228794 (2010).

25. V. Thangadurai, C. Knittlmayer, and W. Weppner, "Metathetic Room Temperature Preparation and Characterization of Scheelite-type $\mathrm{ABO}_{4}(\mathrm{~A}=\mathrm{Ca}, \mathrm{Sr}, \mathrm{Ba}, \mathrm{Pb} ; \mathrm{B}=\mathrm{Mo}, \mathrm{W})$ powders," Mater. Sci. Eng. B, 106 [3] 228-33 (2004).

26. C. S. Lim, "Cyclic MAM Synthesis and Upconversion Photoluminescence Properties of $\mathrm{CaMoO}_{4}: \mathrm{Er}^{3+} / \mathrm{Yb}^{3+}$ Particles,"
Mater. Res. Bull., 47 [12] 4220-25 (2012).

27. W. Lu, L. Cheng, J. Sun, H. Zhong, X. Li, Y. Tian, J. Wan, Y. Zheng, L. Huang, T. Yu, H. Yu, and B. Chen, "The Concentration Effect of Upconversion Luminescence Properties in $\mathrm{Er}^{3+} / \mathrm{Yb}^{3+}$-codoped $\mathrm{Y}_{2}\left(\mathrm{MoO}_{4}\right)_{3}$ Phosphors," Phys. B, 405 [16] 3284-88 (2010).

28. J. Sun, B. Xue, and H. Du, "Synthesis and Luminescence Properties of $\mathrm{Gd}_{6}\left(\mathrm{MoO}_{4}\right)_{12}: \mathrm{Yb}^{3+}, \mathrm{Er}^{3+}$ Phosphor with Enhanced Photoluminescence by $\mathrm{Li}^{+}$Doping," Infr. Phys. Tech., 60 10-14 (2013).

29. Q. Sun, X. Chen, Z. Liu, F. Wang, Z. Jiang, and C. Wang, "Enhancement of the Upconversion Luminescence Intensity in $\mathrm{Er}^{3+}$ Doped $\mathrm{BaTiO}_{3}$ Nanocrystals by Codoping with $\mathrm{Li}^{+}$Ions," J. Alloys Compd., 509 [17] 5336-40 (2012). 